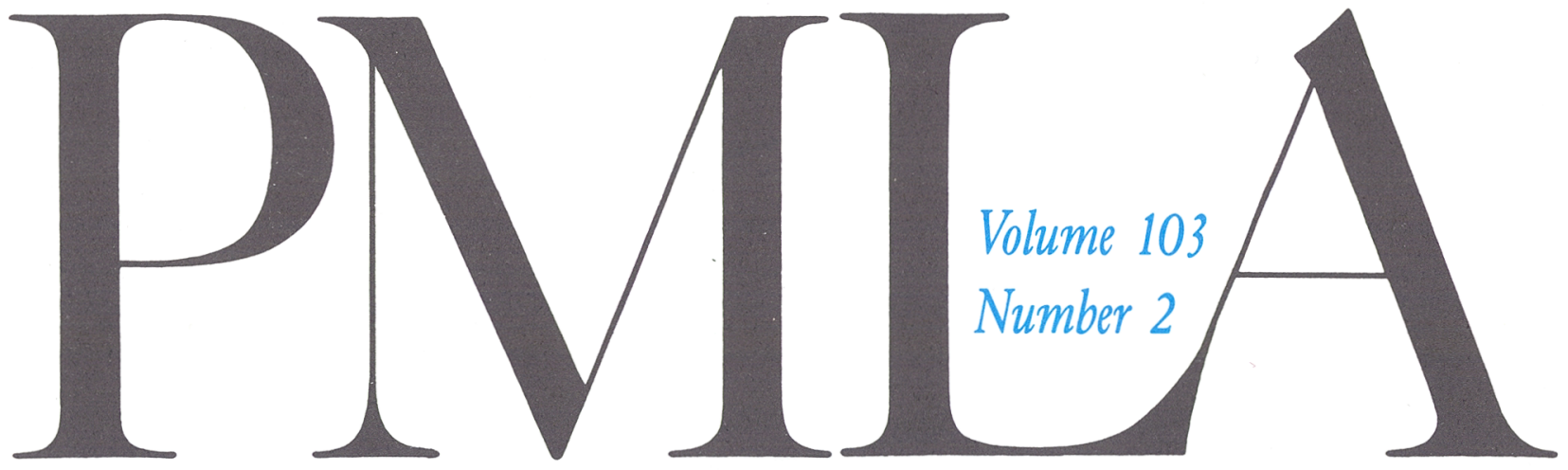

\title{
Publications of the
}

Modern Language Association of America 


\section{The Collected Letters of William Morris}

Volume II, Part A: 1881-1884

Volume II, Part B: 1885-1888

Edited by Norman Kelvin

These volumes continue the only complete edition of the surviving correspondence of William Morris (1834-1896), a protean figure who exerted a major influence as poet, craftsman, master printer, and designer. Covering the years 1881 through 1888, they treat the most dramatic period in another facet of Morris's career: his work as a political activist. There are new documents in great numbers in these volumes, as in the first, and readers "for many years to come will be indebted to Mr. Kelvin for his splendid achievement."

-William S. Peterson, New York Times Book Review

Volume II, Part A

Cloth: $\$ 45.00$ ISBN 0-691-06600-0

Volume II, Part B

Cloth: \$49.50 ISBN 0-691-06723-6

\section{Redesigning the World}

William Morris, the 1880s, and the Arts and Crafts

Peter Stansky

“. . a very readable and enjoyable book. It is not so much a biography of William Morris as a consideration of him as a political and an esthetic phenomenon and as the founder of a number of organizations....Mr. Stansky examines them with a learning that is never pedantic, frequently humorous and always intelligent."

-Quentin Bell, The New York Times Book Review

Paper: \$12.95 ISBN 0-691-01411-6

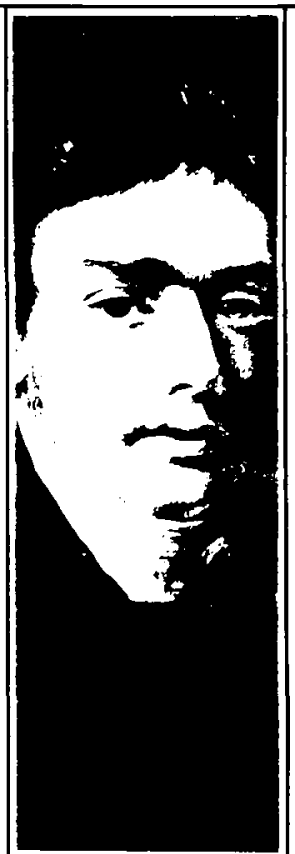

Coleridge and Wordsworth

A Lyrical Dialogue

\section{Paul Magnuson}

Paul Magnuson contends that the relationship between Coleridge's and Wordsworth's poetry is so complex that a new criticism is required to trace its intricacies. This book demonstrates that their poems may be read as parts of a single evolving whole, a "dialogue" in which the works of one are responses to and rewritings of those of the other.

Professor Magnuson discloses this dialogue as a joint canon, or sequence, which includes the complete early versions of poems, as well as fragments, canceled drafts, and poems in progress. He further shows that this sequence is based on lyric structure: the relations among its poems and fragments resemble those among stanzas in an ode. Cloth: $\$ 35.00$ ISBN 0-691-06732-5

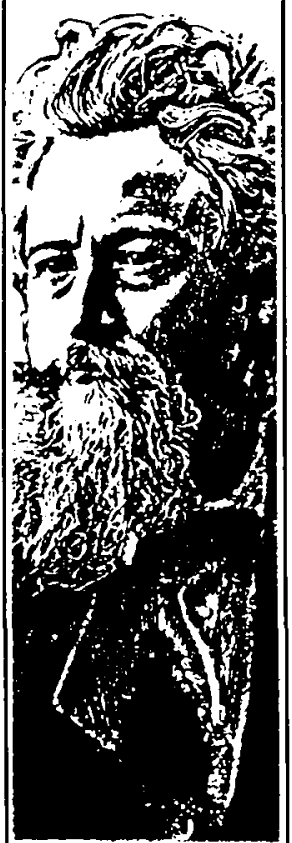

\section{The Power of Historical Knowledge}

Narrating the Past in Hawthorne, James, and Dreiser

Susan L. Mizruchi

In this provocative study, Susan Mizruchi argues that the act of writing history is the key to the political concerns of American novelists. Using nineteenth-century theories of history as well as recent narratological models, she examines reconstructions of the past in The House of the Seven Gables (1851), The Bostonians (1886), The Wings of the Dove (1902), and An American Tragedy (1925). Her focus allows readers to see that the efforts (on the part of characters and narrators alike) to reshape the past reveal both anxieties about the self and larger struggles for political power. Cloth: \$32.50 ISBN 0-691-06725-2 
March 1988

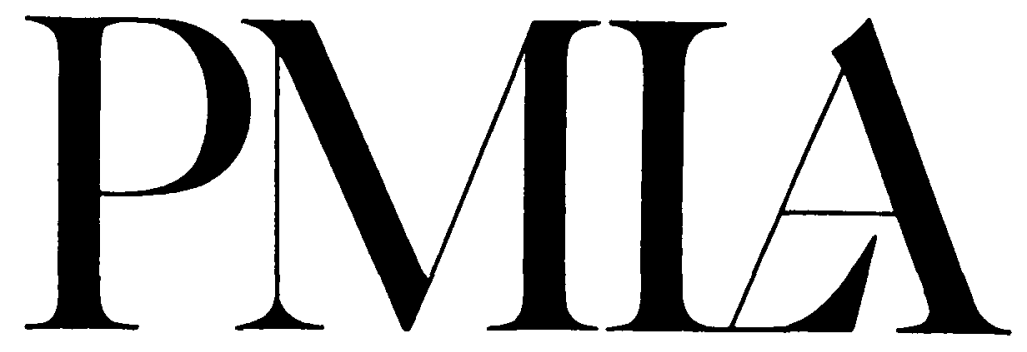

Publications of the

Modern Language Association of America 


\title{
The Modern Language Association of America ORGANIZED 1883 \\ INCORPORATED 1900
}

\author{
OFFICERS FOR THE YEAR 1988 \\ President: Barbara Herrnstein Smith, Duke University \\ First Vice President: VICTOR Brombert, Princeton University \\ Executive Director: Phyllis Franklin \\ Deputy Executive Director and Treasurer: HaNs RÜtIMANN
}

\section{EXECUTIVE COUNCIL}

For the term ending 31 December 1988

Mary Louise Pratt

Stanford University

FRANK J. WARNKE

University of Georgia

Ruth BERNARd Yeazell

University of California, Los Angeles

For the term ending 31 December 1990

Thomas M. Greene

Yale University

LAWRENCE LIPKING

Northwestern University

JUDITH RYAN

Harvard University
For the term ending 31 December 1989

Peter Elbow

University of Massachusetts, Amherst

JoAn M. FERRANTE

Columbia University

Patricia M. Spacks

Yale University

For the term ending 31 December 1991

JoAN DeJEAN

Princeton University

Frances Ferguson

University of California, Berkeley

MYRA JEHLEN

Rutgers University, New Brunswick

\section{TRUSTEES OF INVESTED FUNDS}

William O. Baker
Murray Hill, New Jersey
Joel Conarroe (Managing Trustee)

New York, New York

\author{
Malcolm SMITH \\ New York, New York
}

PMLA (ISSN 0030-8129) is issued six times a year, in January, March, May, September, October, and November, by the Modern Language Association of America. Membership is open to those persons who are professionally interested in the modern languages and literatures. Annual dues, which include subscription to PMLA, are based on members' salaries and are graduated as follows: student members (four years maximum), \$10; new regular members (first year), $\$ 25$; regular members (salary under $\$ 12,000$ ), $\$ 10$; regular members (salary $\$ 12,000-\$ 15,000$ ), $\$ 35$; regular members (salary $\$ 15,000-\$ 20,000$ ), $\$ 45$; regular members (salary $\$ 20,000-\$ 25,000$ ), $\$ 50$; regular members (salary $\$ 25,000-\$ 30,000$ ), $\$ 55$; regular members (salary $\$ 30,000-\$ 35,000$ ), $\$ 60$; regular members (salary $\$ 35,000-\$ 40,000$ ), $\$ 65$; regular members (salary $\$ 40,000-\$ 45,000$ ), $\$ 70$; regular members (salary $\$ 45,000-\$ 50,000$ ), $\$ 75$; regular members (salary $\$ 50,000-\$ 55,000$ ), $\$ 80$; regular members (salary $\$ 55,000-\$ 60,000$ ), $\$ 85$; regular members (salary $\$ 60,000-\$ 65,000$ ), $\$ 90$; regular members (salary $\$ 65,000-\$ 70,000$ ), \$95; regular members (salary $\$ 70,000-\$ 75,000$ ), $\$ 100$; regular members (salary $\$ 75,000$ and above), \$105; joint members (two individuals sharing the same household, who receive one subscription to $P M L A$ but two copies of all other publications), add $\$ 20$ to dues category of higher-income member; foreign members, same as regular members (ascertain dues category based on American dollar equivalent). Membership applications are available on request.

The subscription price of $P M L A$ for libraries and other institutions is $\$ 80$. A subscription including a bound volume at the end of the year is $\$ 195$, domestic and foreign. Agents deduct $4 \%$ as their fee. Single copies of the January, March, May, and October issues may be obtained for $\$ 7.50$ each; the November (Program) issue for $\$ 20$; the September (Directory) issue for $\$ 35$.

Issues for the current year are available from the MLA Member and Customer Services Office. Claims for undelivered issues will be honored if they are received within one year of the publication date; thereafter the single issue price will be charged.

For information about the availability of back issues, inquire of Kraus Reprint Co., Millwood, NY 10546; (914) 762-2200. Early and current volumes may be obtained on microfilm from University Microfilms, Ann Arbor, MI 48106. Purchase of current volumes on film is restricted to subscribers of the journal.

\section{OFFICE OF PUBLICATION AND EDITORIAL OFFICES} 10 Astor Place, New York, NY 10003-6981

All communications including notices of changes of address should be sent to the Member and Customer Services Office of the Association. If a change of address also involves a change of institutional affiliation, that office should be informed of this fact at the same time.

Second-class postage paid at New York, NY, and at additional mailing office.

Copyright (C) 1988 by The Modern Language Association of America.

Library of Congress Catalog Card Number 12-32040.

POSTMASTER: Send address changes to Member and Customer Services Office, Modern Language Association of America, 10 Astor Place, New York, NY 10003-6981. 


\title{
Contents $\cdot$ March
}

Editor's Column . . . . .

Notes on Contributors

109

Forthcoming in $P M L A$

109

Special Topics . . . . . . . . . . .

Joseph's Bones and the Resurrection of the Text: Remembering in the Bible. REgina M. Schwartz

\begin{abstract}
The Hebrew Bible depicts interpretation as a continual process of losing and finding, of forgetting and remembering. Texts are lost and found, and in the Joseph story (Gen. 37-50), Joseph himself is abandoned and recovered, with all memory of him repressed until it is dramatically recalled. His story demonstrates that repression is the condition of interpretation, and that interpretation-not resurrection-holds forth the promise of a future life. Nonetheless, the repeated losses that punctuate the Joseph narrative have inspired the opposite conclusion: that Joseph is a type of Jesus, that his descents and ascents prefigure the final one. Typology, a mode of biblical interpretation that prevailed during the early church, has enjoyed a recent revival in the context of literary studies; but I argue that the typological language of "fulfillment,", of shadows and truth, is alien to Hebraic-and postmodern-understandings of textuality. (RMS)
\end{abstract}

\section{Feminist Thematics and Shakespearean Tragedy.}

RICHARD LEVIN . . . . . . . . . .

\begin{abstract}
The thematic approach adopted by a number of feminist critics of Shakespearean tragedy raises serious problems. Some of these are inherent in thematism itself, such as the need to select the facts of the play to fit the theme and to manipulate the theme to fit the facts. But other problems are peculiar to their choice of "gender conflict" or "patriarchy" as the central theme that is the subject of these tragedies and the cause of their outcomes. This leads to the confusion of a necessary condition with a sufficient cause and to difficulties in their treatments of the protagonists, the emotional effects, the tragic genre, and the role of the author, who is supposed to be condemning "patriarchy" in these plays. Further problems arise because of the particular conception of masculinity that some of these critics bring to their readings. (RL)
\end{abstract}

A Vampire in the Mirror: The Sexuality of Dracula. John Allen Stevenson

\begin{abstract}
Vampire sexuality, as represented in Bram Stoker's Dracula, reveals itself both as a phenomenon that is terrifyingly foreign to typical experience and, paradoxically, as a distorted mirror of human behavior. On the one hand, the vampire inspires a xenophobic response because his needs violate the normal limits of exogamy: he is physiologically dependent on women who are foreign to him. On the other hand, the novel undermines the very idea of the "foreign" by suggesting that even the most bizarre aspects of a vampire's sex life are strangely familiar-usually because they parody or literalize human sexuality. (JAS)
\end{abstract}


History and Romance, Sympathy and Uncertainty: The Moral of the Stones in Hawthorne's Marble Faun. JoHN MICHAEL . .

\begin{abstract}
Hawthorne attempted not only to change his readers' understanding of historical events but also to undermine their complacency about historical understanding. In The Marble Faun, he questions the positivistic assumptions and complacent moralism of nineteenth-century historiography by representing sympathy and estrangement as principles of knowledge. The story of Kenyon and Hilda, Miriam, Donatello, and the model, set amid the ruins of Rome, indicates that both the truths of history and the truths of the human heart are produced in narratives that reflect the affective links between the tellers of tales and the objects described. For Hawthorne history and romance are not morally or epistemologically distinct. Sympathy does not solve the problem of historical knowledge but reposes it in a form more proper to the ambiguities of romance as Hawthorne used the genre than to the certainties of history as traditionally conceived. (JM)
\end{abstract}

\title{
"Don't Tell": Imposed Silences in The Color Purple and The Woman Warrior. KING-KoK CheUng
}

\begin{abstract}
The Color Purple and The Woman Warrior exhibit parallel narrative strategies. The respectively black and Chinese American protagonists work their way from speechlessness to eloquence by breaking through the constraints of sex, race, and language. The heroines turn to masculine figures for guidance, to female models for inspiration, and to native idioms for stylistic innovation. Initially unable to speak, they develop distinctive voices by registering their own unspoken grief on paper and, more important, by recording and emulating the voices of women from their respective ethnic communities. Through these testimonies, each written in a bicultural language, Walker and Kingston reveal the obstacles and resources peculiar to minority women. Subverting patriarchal literary traditions by reclaiming a mother tongue that carries a rich oral tradition (of which women are guardians) the authors artfully coordinate the tasks of breaking silence, acknowledging female influence, and redefining while preserving ethnic characteristics. (KKC)
\end{abstract}

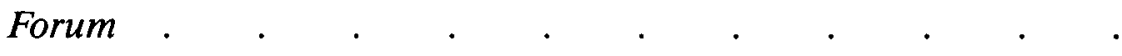

Forthcoming Meetings and Conferences of General Interest .

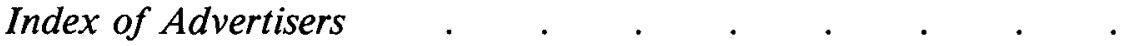

Professional Notes and Comment . . . . . . 


\section{EDITORIAL BOARD}

Marshall Brown, 1989 University of Colorado, Boulder

Margaret Williams Ferguson, 1988 Columbia University

SUSAN HaRdy AIKEN, 1989
University of Arizona

Terry J. Castle, 1990

Stanford University

Ross Chambers, 1991

University of Michigan, Ann Arbor

Leopold Damrosch, JR., 1991

University of Maryland, College Park

FREDERICK A. DE ARMAS, 1989

Louisiana State University,

Baton Rouge

Heather Dubrow, 1990

Carleton College

George D. Economou, 1990

University of Oklahoma

DANIEL MARK Fogel, 1990

Louisiana State University, Baton Rouge

JEAN Franco, 1988

Columbia University

Frederick Goldin, 1991

City College and

Graduate Center

City University of New York
Henry Louis Gates, JR., 1988

Cornell University

Herbert S. LINDENBERGER, 1988

Stanford University

\section{ADVISORY COMMITTEE}

RichaRd HELGERSON, 1988

University of California, Santa Barbara

MARGaRET HoMans, 1991

Yale University

Peggy Kamuf, 1989

Miami University

Marjorie Beth Levinson, 1990

University of Pennsylvania

Deborah E. McDowell, 1989

University of Virginia

TANIA Modleski, 1991

University of Southern California

Gary SaUl Morson, 1991

Northwestern University

JAMES J. MURPhy, 1989

University of California, Davis

JoHANNA Nichols, 1991

University of California, Berkeley

MARGOT C. Norris, 1990

University of California, Irvine

Jonathan F. S. Post, 1989

University of California, Los Angeles
RoBert Scholes, 1989

Brown University

NAOMI SchoR, 1989

Brown University

FrançoIs Rigolot, 1988

Princeton University

RoBert J. RODINI, 1991

University of Wisconsin, Madison

EgON SCHWARZ, 1991

Washington University

JoSEPH T. SKERRETT, JR., 1989

University of Massachusetts, Amherst

RoNALD SUKENICK, 1990

University of Colorado, Boulder

ERIC J. SUNDQUIST, 1991

University of California, Berkeley

EUGene VANCE, 1990

Emory University

ThLlY WaRNock, 1989

University of Wyoming

Thomas Russell Whitaker, 1990

Yale University

GEORGE T. WRIGHT, 1990

University of Minnesota, Minneapolis

Editor: JOHN W. KRONIK, Cornell University

Editorial Supervisor: ClarRe COOK

Assistant Editor: BonNIE V. LeVY

Managing Editor: JudY GouldiNG Assistant Managing Editor: RosLYN SCHLOSS Assistant Editor: ElIZABETH Holland

\section{A STATEMENT OF EDITORIAL POLICY}

$P M L A$ welcomes essays of interest to those concerned with the study of language and literature. As the publication of a large and heterogeneous association, the journal is receptive to a variety of topics, whether general or specific, and to all scholarly methods and theoretical perspectives. The ideal $P M L A$ essay exemplifies the best of its kind, whatever the kind; addresses a significant problem; draws out clearly the implications of its findings; and engages the attention of its audience through a concise, readable presentation. Articles of fewer than 2,500 words or more than 9,000 words are not considered for publication. The word count includes notes but excludes translations, which should accompany foreign language quotations. The MLA urges its contributors to be sensitive to the social implications of language and to seek wording free of discriminatory overtones.

Only members of the association may submit articles to $P M L A$. Each article submitted is sent to at least one consultant reader and one member of the Advisory Committee. Articles recommended by these readers are then sent to the members of the Editorial Board, who meet periodically with the editor to make final decisions. Until a final decision is reached, the author's name is not made known to consultant readers, to members of the Advisory Committee and the Editorial Board, or to the editor.

Submissions, prepared according to The MLA Style Manual, should be addressed to the Editor of PMLA, 10 Astor Place, New York, NY 10003-6981. An author's name should not appear on the manuscript; instead, a cover sheet, with the author's name, address, and the title of the article, should accompany the article. Authors should not refer to themselves in the first person in the submitted text or notes if such references would identify them; any necessary references to the author's previous work, for example, should be in the third person. 